\title{
HUBUNGAN PEMELIHARAAN KESEHATAN GIGI DENGAN STATUS KARIES GIGI SISWA KELAS 1 SMP 1 MUHAMMADIYAH KECAMATAN PADANG TIMUR KOTA PADANG
}

\author{
Dio Ervan ${ }^{1}$, Lendrawati $^{2}$, Detty Irwan $^{3}$ \\ ${ }^{1}$ Faculty of Dentistry Andalas University \\ ${ }^{2}$ Departemen of Dental Public Health Faculty of Dentristry Andalas University \\ ${ }^{3}$ Faculty of Medicine Andalas University
}

\begin{abstract}
Dental caries is infection diseases caused by email and dentin demineralization that related to consume cariogenic food. Caries caused by interactions between the host, agent, substrate, and time.Attitude and behaviour of dental health maintenance is one of predisposising factor dental caries status. This study aims to determine the correlation of dental health maintenance with dental caries status in junior high school first grade.This study used a cross sectional design. The sample was first grade students of junior high school Muhammadiyah Padang, sample in this study is 120 students by using total sampling method. The dental health maintenance obtained through questionnaire and dental caries status was examined using DMF-T indexs. Statistic analysis was perfomed using chi square test. 54,2\% students have good dental health maintenance category and 55,8\% students have low dental caries category. Statistic analysis test showed significant correlation between dental health maintenance with dental caries status, $p$ value $=0,00$ $(p<0,05)$. There is a correlation between dental health maintenance with dental caries status. Dental health maintenance first grade students of junior high school 1 Muhammadiyah Padang is good and dental caries status is low category
\end{abstract}

Keywords: dental caries, DMF-T, dental caries status, dental health maintenance.

Affiliasi penulis: ${ }^{1}$ Faculty of Dentistry Andalas University

Korespondensi: Dio Ervan

email:

\section{PENDAHULUAN}

Karies gigi di Indonesia merupakan masalah kesehatan gigi dan mulut yang masih perlu mendapat perhatian. Karies gigi merupakan penyakit infeksi yang disebabkan oleh demineralisasi email dan dentin yang erat hubungannya dengan konsumsi makanan yang kariogenik dan terjadinya karies gigi akibat peran dari bakteri utama penyebab karies yaitu Streptococcus Mutans (Worotitdjan, 2013) . Karies gigi menjadi masalah kesehatan yang penting karena kelainan pada gigi ini dapat menyerang siapa saja tanpa memandang usia dan jika dibiarkan berlanjut akan merupakan sumber fokal infeksi dalam mulut sehingga menyebabkan keluhan rasa sakit (Sari dkk, 2012) ${ }^{2}$.

Di Negara-negara maju prevalensi karies gigi terus menurun, sedangkan di negara-negara berkembang seperti Indonesia cenderung meningkat dan Berdasarkan data RISKESDAS pada tahun 2007 didapatkan bahwa penduduk Indonesia yang mempunyai pengalaman karies sebesar $72,1 \%$ dan penduduk yang mengalami karies aktif sebesar 46,5\%dan 
indeks DMF-T penduduk Indonesia sebesar 4,85 (Depkes RI, 2008)3.

Berdasarkan data RISKESDAS 2007 Penduduk pada Provinsi Sumatera Barat yang mempunyai pengalaman karies sebesar 70,6\% dan penduduk yang mengalami karies aktif sebesar 41,6\% dan indeks DMF-T penduduk Sumatera Barat sebesar 5,25 dan berdasarkan data RISKESDAS pada tahun 2007 prevalensi karies pada anak umur 10-14 tahun di Indonesia sebesar 20,6\% (Depkes RI,2008) ${ }^{3}$. Berdasarkan data Depertemen Kesehatan pada tahun 2009 sebanyak 89\% anak Indonesia di bawah umur 12 tahun menderita karies (Wala dkk, 2013) . $^{4}$

Karies gigi yang terjadi pada anak akan mengakibatkan munculnya rasa sakit sehingga anak menjadi malas makan dan juga dapat menyebabkan tulang di sekitar gigi menjadi terinfeksi. Apabila terjadi kerusakan pada tahap yang berat atau sudah terjadi abses, maka gigi dapat tanggal.Anak yang kehilangan beberapa giginya tidak dapat makan dengan baik kecuali makanan yang lunak (Hidayanti, $2005)^{5}$.

Banyak faktor yang dapat menyebabkan terjadinya karies gigi, baik pada anak maupun orang dewasa. Ada empat faktor utama penyebab karies adalah host, agent, substrat, dan waktu, selain empat faktor utama penyebab karies gigi, terdapat faktor predisposisi yang berhubungan secara tidak langsung dengan terjadinya karies gigi, antara lain usia yaitu semakin lama gigi berada dalam mulut, maka faktor resiko karies semakin besar; jenis kelamin yaitu pertumbuhan gigi pada anak perempuan lebih cepat dibandingkan dengan pertumbuhan gigi pada anak laki-laki, sehingga semakin lama gigi berada dirongga mulut yang menyebabkan resiko karies semakin besar (Jovina, 2010) ${ }^{6}$.

Faktor predisposisi lainnya adalah letak geografis yaitu karena kultur dan pola diet yang berbeda pada setiap daerah; faktor tingkat sosial ekonomi, yaitu semakin tinggi sosial ekonomi seseorang, maka semakin tinggi kesadaran dan pengetahuan tentang memelihara kesehatan gigi dan mulut; sikap dan perilaku terhadap pemeliharaan kesehatan gigi antara lain kebersihan mulut yang berhubungan dengan frekuensi dan kebiasaan menggosok gigi, jumlah dan frekuensi makan makanan kariogenik yang menyebabkan karies. ${ }^{6}$

Pemeliharaan kesehatan gigi mulut merupakan perilaku atau usahausaha seseorang untuk memelihara kesehatan gigi dan mulut agar terhindar dari penyakit gigi mulut dan usaha untuk penyembuhan jika menderita penyakit gigi mulut. Tindakan tersebut meliputi 
menyikat gigi, berkumur-kumur setelah makan dengan air putih, pemberian flour, pemeriksaan gigi ke dokter gigi, dan mengurangi makan makanan yang manis (Saragih, 2009) ${ }^{7}$.

Upaya pemeliharaan kesehatan gigi mulut serta pembinaan kesehatan gigi pada anak sekolah perlu mendapat perhatian khusus sebab pada usia ini anak sedang menjalani proses tumbuh kembang. Keadaan gigi sebelumnya akan berpengaruh terhadap kesehatan gigi pada usia dewasa nanti (Pradita dkk, 2013) ${ }^{8}$.

WHO merekomendasikan

kelompok umur tertentu untuk dilakukan pemeriksaan karies gigi yaitu kelompok umur 5 tahun untuk gigi susu dan 12,15, 35-44 dan 65-74 tahun untuk gigi permanen. Jumlah subjek yang diperiksa untuk setiap kelompok umur minimal 2550 orang untuk setiap kelompok.Kelompok umur 12 tahun ini penting untuk diperiksa karena umumnya anak-anak meninggalkan bangku sekolah dasar pada umur 12 tahun.Selain itu, semua gigi permanen diperkirakan sudah erupsi pada kelompok umur ini kecuali gigi molar tiga.Berdasarkan ini, umur 12 tahun ditetapkan sebagai umur pemantauan global (global monitoring age) untuk karies (Pintauli dan Hamada, $2008)^{9}$.

Pada penelitian yang dilakukan oleh Dumasari Barus (2009) tentang hubungan kebiasaan makan dan pemeliharaan kesehatan gigi dengan karies gigi pada anak kelas IV, V, dan VI SD 060935di Jalan Pintu Air Ii Simpang Gudang Kota Medan tahun 2008 disimpulkan bahwa terdapat hubungan bermakna antara tindakan pemeliharaan kesehatan gigi dengan karies gigi (Barus, 2009 $)^{10}$. Hasil penelitian Jesica N. Sihite (2011) menunjukkan hubungan yang bermakna antara perilaku pemeliharaan kesehatan gigi dan mulut dengan pengalaman karies (DMF-T) dan indeks oral hygiene (OHI-S) pada siswa SMP Nurul Hasannah Kota Medan (Sihite, $2011)^{11}$.

Data dari Dinas Kesehatan Kota Padang tahun 2012 didapatkan bahwa wilayah kerja puskesmas dengan kunjungan karies tertinggi terdapat di puskesmas andalas dengan kunjungan karies sebanyak 348 kunjungan (Dinkes Padang, 2012) ${ }^{12}$. Pada wilayah kerja puskesmas andalas terdapat 12 Sekolah Menengah Pertama. Berdasarkan laporan screening yang dilakukan oleh Puskesmas Andalas tahun 2013, SMP dengan kejadian karies terbanyak adalah SMP 1 Muhammadiyah Kecamatan Padang Timur Kota Padang yaitu 86 (47\%) siswa dari 183 siswa kelas 1 yang di periksa terkena karies (Puskesmas Andalas, 
2013) $)^{13}$.

Berdasarkan alasan-alasan di atas, maka peneliti tertarik untuk melakukan penelitian mengenai "Hubungan Pemeliharaan Kesehatan Gigi Dengan Status Karies Gigi Pada siswa kelas 1 SMP Muhammadiyah Kecamatan Padang Timur Kota Padang".

\section{METODE PENELITIAN}

Penelitian dilakukan di SMP 1 Muhammadiyah Kecamatan Padang Timur Kota Padang pada bulan Juni 2014. Populasi pada penelitian ini adalahSiswa Kelas 1 SMP 1 Muhammadiyah Kecamatan Padang Timur Kota Padang. Sampel pada penelitian ini berjumlah 186 siswa.Peneliti memakai metode pengambilan sampel yaitu Total Sampling.

Pemeriksaan status karies gigi dilakukan dengan menggunakan kaca mulut dan sonde pada masing-masing sampel secara teliti dengan menggunakan indeks DMF-T. Data pemeliharaan kesehatan gigi didapat melalui pengisian kuisioner oleh responden yang telah diberi bimbingan dan arahan oleh peneliti dan dilakukan analisa data untuk melihat hubungan antara dua variabel yaitu variabel independen dan variable independen dengan menggunakan metode chi-square.

\section{HASIL PENELITIAN}

Tabel 5.1 Gambaran pemeliharaan kesehatan gigi dengan status karies

\begin{tabular}{|c|c|c|c|c|}
\hline \multirow[b]{2}{*}{ Pemeliharaan } & \multicolumn{3}{|c|}{ Status karires } & \multirow[b]{2}{*}{ Total } \\
\hline & Rendah & $\begin{array}{c}\text { Sedan } \\
\mathrm{g}\end{array}$ & Tinggi & \\
\hline \multirow{3}{*}{ Baik } & $\mathrm{n}$ & $\mathrm{n}$ & $\mathrm{n}$ & $\mathrm{n}$ \\
\hline & 57 & 8 & 0 & 65 \\
\hline & $87,7 \%$ & $12,3 \%$ & 0 & $\begin{array}{l}100 \\
\%\end{array}$ \\
\hline \multirow[t]{2}{*}{ Sedang } & 10 & 29 & 3 & 42 \\
\hline & $32,8 \%$ & $69 \%$ & $7,2 \%$ & $\begin{array}{l}100 \\
\%\end{array}$ \\
\hline \multirow[t]{3}{*}{ Kurang } & 0 & 2 & 11 & 13 \\
\hline & 0 & $15,4 \%$ & $84,6 \%$ & 100 \\
\hline & & & & $\%$ \\
\hline \multirow[t]{3}{*}{ Total } & 67 & 39 & 14 & 120 \\
\hline & $55,8 \%$ & $32,5 \%$ & $11,7 \%$ & 100 \\
\hline & & & & $\%$ \\
\hline
\end{tabular}

Pada tabel 5.1 terlihat bahwa siswa dengan kategori pemeliharaan yang baik sebanyak $87,7 \%$ siswa mempunyai status karies rendah, siswa dengan kategori pemeliharaan sedang sebanyak 69\% siswa mempunyai status karies sedang, dan siswa dengan kategori pemeliharaan yang kurang sebanyak $84,6 \%$ siswa mempunyai status karies tinggi.

Berdasarkan uji statistik yang telah dilakukan terdapat hubungan antara pemeliharaan kesehatan gigi dengan status karies gigi dengan nilai $\mathrm{p}=0,00(\mathrm{p}<$ $0,05)$.

\section{PEMBAHASAN}

Penelitian ini bertujuan untuk mengetahui hubungan antara pemeliharaan kesehatan gigi dengan status karies gigi pada siswa kelas satu 
Sekolah Menengah Pertama Muhammadiyah 1 Kecamatan Padang Timur Kota Padang.Penelitian ini dilakukan dalam dua tahap yaitu pengisian kuisioner untuk menilai tindakan pemeliharaan kesehatan gigi yang dilakukan oleh siswa dan pemeriksaan indeks DMF-T untuk mengetahui status karies gigi siswa.

Dalam menilai pemeliharaan kesehatan gigi terdapat tiga kategori yaitu pemeliharaan baik dengan skor 21-27, sedang 15-20, dan kurang 9-14. Dari hasil penelitian didapatkan bahwa siswa dengan pemeliharaan kategori baik 54,2\% siswa, sedang $35 \%$ siswa,dan kurang 10,8\% siswa. Tindakan pemeliharaan kesehatan gigi dilihat dari kebiasaan menyikat gigi, konsumsi buah dan sayur, mengurangi konsumsi makanan kariogenik, berkumur-kumur, kunjungan rutin ke dokter gigi dan,pemberian flour melalui penggunaan pasta gigi yang mengandung flour.

Pada tindakan kebiasaan menyikat gigi $85 \%$ siswa telah mengetahui frekuensi menyikat gigi yang benar, tetapi lebih dari separuh siswa belum mengetahui waktu dan teknik menyikat gigi yang benar.Waktu yang disarankan untuk menyikat gigi yaitu setiap sesudah sarapan pagi dan sebelum tidur malam. Hal ini disarankan karena pada waktu malam aliran saliva serta pergerakan mulut berkurang sehingga daya untuk membersihkan gigi dari sisa makanan juga menurun yang menyebabkan bakteri dalam mulut berkembang pesat dua kali lipat dibandingkan dengan siang hari.Metode penyikatan gigi yang dianjurkan adalah metode bass (Angela, 2005; Noviani, 2010; Jovina, 2010) $)^{6,14,15}$.

Pada tindakan konsumsi buah dan sayur, $37,5 \%$ siswa mengonsumsi buah dan sayur beberapa kali seminggu. Tindakan mengonsumsi buah dan sayur merupakan salah satu tindakan pemeliharaan kesehatan gigi yang penting karena dapat mengurangi terjadinya karies gigi karena buah-buahan dan sayursayuran dapat meningkatkan fungsi pengunyahan serta merangsang sekresi saliva dimana saliva memiliki beberapa fungsi diantaranya sebagai self cleansing, buffer saliva, dan antibakteri. Sebaiknya konsumsi buah dan sayur ini dilakukan setiap setelah makan (Bachtiar dkk, 2005; Almeida dkk, 2008 Barus, 2009; Jovina, 2010). ${ }^{6,10,16,17}$

Pada tindakan mengurangi konsumsi makanan kariogenik sepertiga siswa $(32,5 \%)$ mengonsumsi makanan kariogenik empat kali atau lebih dalam sehari. Kebiasaan ini menyebabkan resiko terjadinya karies meningkat. Hal ini terjadi karena frekuensi konsumsi 
makanan kariogenik 4 kali atau lebih dalam sehari mempengaruhi timbulnya karies pada gigi seseorang (Loveren, 2003). ${ }^{18}$

Pada tindakan berkumur-kumur, sebagian besar siswa yaitu $42,5 \%$ siswa masih belum mengetahui pentingnya berkumur-kumur dengan air putih setelah makan. Kebiasaan berkumur-kumur setelah makan merupakan salah satu pemeliharaan kesehatan gigi yang penting karena berkumur kumur setelah makan dengan menggunakan air putih akan mengurangi debris atau sisa makanan yang terselip diantara gigi yang mengurangi pembentukkan plak gigi sehingga dengan sendirinya mengurangi resiko terjadinya karies dan berkumur kumur dengan air putih dapat menetralkan $\mathrm{Ph}$ mulut (Sari dkk, 2012;Hiremath, SS, $2011)^{2,19 .}$

Pada kunjungan rutin ke dokter gigi, sebagian besar siswa yaitu 55,8\% ke dokter gigi bila sakit saja. Kunjungan rutin ke dokter gigi minimal dilakukan dua kali setahun meskipun gigi dalam keadaan sehat yang bertujuan untuk konsultasi gigi dan pencegahan dini karies gigi (Notohartojo dkk, 2011) ${ }^{20}$.

Pada aplikasi pasta gigi yang mengandung flour, $96,7 \%$ siswa menggunakan pasta gigi berflour saat menyikat gigi. Penggunaan pasta gigi yang mengandung flour harus dianjurkan untuk semua orang terlepas dari apakah orang itu memiliki resiko karies yang tinggi, sedang, atau rendah.Penyikatan gigi dengan pasta gigi yang mengandung flour terbukti dapat menurunkan resiko karies gigi (Tarigan, 2013) ${ }^{21}$.

Status karies gigi dinilai dari pemeriksaan indeks DMF-T $(\mathrm{D}$ (decay) $=$ jumlah gigi karies yang masih dapat ditambal, $\mathrm{M}$ (missing) = jumlah gigi permanen yang hilang atau harus dicabut karena karies yang tidak dapat ditambal lagi, $\mathrm{F}$ (filling) = jumlah gigi permanen yang telah ditambal) dengan indeks DMFT rendah 0,0-2,6, sedang 2,7-4,4, dan tinggi 4,5->6,6. Dari hasil penelitian didapatkan bahwa siswa dengan indeks DMFT rendah 55,8\% siswa, sedang $32,5 \%$ siswa dan tinggi $11,7 \%$ siswa. DMF-T rerata seluruh siswa dalam penelitian ini 2,19 termasuk dalam kategori rendah.

Dari hasil penelitian juga didapatkan bahwa pada anak yang pola pemeliharaan kesehatan giginya baik sebagian besar memiliki status karies yang rendah, pada anak yang pola pemeliharaan kesehatan giginya buruk sebagian besar status kariesnya tinggi, dan pada anak yang pemeliharaanya sedang sebagian besar memiliki status karies sedang. Hal ini menunjukkan bahwa 
pemeliharaan kesehatan gigi berpengaruh terhadap status karies dimana semakin kurang baik pemeliharaan kesehatan gigi seseorang maka semakin tinggi status kariesnya dan sebaliknya.

Hal ini juga terbukti dari hasil uji statistik yang dilakukan, terlihat bahwa nilai $\mathrm{p}=0,00(\mathrm{p}<0,05)$ yang menunjukkan bahwa terdapat hubungan antara pemeliharaan kesehatan gigi dengan status karies gigi siswa kelas satu Sekolah Menengah Pertama Muhammadiyah Kecamatan Padang Timur Kota Padang. Hal ini sesuai dengan penelitian yang dilakukan oleh Dumasari Barus (2009) tentang hubungan kebiasaan makan dan pemeliharaan kesehatan gigi dengan karies gigi pada anak kelas IV, V, dan VI SD 060935 di Jalan Pintu Air II Simpang Gudang Kota Medan Tahun 2008. Penelitian tersebut menunjukkan bahwa terdapat hubungan yang bermakna antara tindakan pemeliharaan kesehatan gigi dengan karies gigi. Hasil penelitian ini juga didukung oleh hasil penelitian Jessica N. Sihite (2011) yang menyimpulkan bahwa terdapat hubungan yang bermakna antara perilaku pemeliharaan kesehatan gigi dan mulut dengan pengalaman karies (DMFT) dan indeks oral hygiene (OHIS-S) pada siswa SMP Nurul Hasannah Kota Medan.

\section{KESIMPULAN}

1. Sebagian besar siswa $(54,2 \%)$ melakukan pemeliharaan kesehatan gigi yang baik.

2. Sebagian besar $\operatorname{siswa}(55,8 \%)$ mempunyai status karies gigi yang rendah.

3. Sebagian besar siswa dengan kategori pemeliharaan kesehatan gigi baik $(87,7 \%)$ mempunyai status karies gigi kategori rendah, sebagian besar siswa dengan kategori pemeliharaan kesehatan gigi kategori sedang (69\%) mempunyai status karies gigi kategori sedang, dan sebagian besar siswa dengan kategori pemeliharaan kesehatan gigi kurang baik $(84,6 \%)$ mempunyai status karies gigi kategori tinggi.

4. Terdapat hubungan pemeliharaan kesehatan gigi dengan status karies gigi.

\section{SARAN}

1. Bagi Puskesmas Setempat Perlu meningkatkan penyuluhan tentang pemeliharaan kesehatan gigi, seperti kebiasaan menyikat gigi, konsumsi buah dan sayur, mengurangi konsumsi makanan kariogenik, berkumur-kumur, kunjungan rutin ke dokter gigi dan pemberian flour melalui penggunaan pasta gigi yang 
mengandung flour.

2. Bagi Sekolah Membuat program kerjasama dengan puskesmas setempat seperti penyuluhan kesehatan gigi berkala atau sikat gigi massal dan lain-lain.

3. Bagi Siswa Diharapkan agar lebih memperhatikan kesehatan gigi dengan memeriksakan gigi secara berkala (minimal 2 kali setahun).

\section{KEPUSTAKAAN}

1. Worotitjan, Indri dkk (2013). Pengalaman Karies Gigi serta Pola Makan Dan Minum Pada Anak Sekolah Dasar Di Desa Kiawa Kecamatan Kawangkan Utara. Jurnal e-Gigi (eg) Vol 1(1), 59-68. Manado.

2. Sari dkk (2012). Pengaruh Pendidikan Kesehatan Metode Simulasi Menggosok Gigi Teknik Modifikasi Bass Dengan Ketrampilan Dan Kebersihan Gigi Mulut Pada Anak Mi At-Taufiq Kelas V. Indonesian Journal of Community Health Nursing vol 1 (1). Surabaya.

3. Depertemen Kesehatan RI (2008). Riset Kesehatan Dasar (RISKESDAS) 2007. Depkes. Jakarta.

4. Wala dkk (2013). Gambaran Status Karies Gigi Anak Usiall- 12 Tahun Pada Keluarga Pemegang Jaskesmas di Kelurahan Tumatangtang I Kecamatan Tomohon Selatan. [Artikel Ilmiah]. Manado.

5. Hidayanti, Lilik (2005). Hubungan Karakteristik Keluarga Dan Kebiasaan Konsumsi Makan Kariogenik Dengan Keparahan Karies Gigi Anak Sekolah Dasar. [Tesis]. Universitas Diponegoro

6. Jovina, Tince Arniati (2010). Pengaruh Kebiasaan Menyikat Gigi Terhadap Status Pengalaman Karies Riskesdas 2007.

[Tesis]. Universitas Indonesia.

7. Sari dkk (2012). Pengaruh Pendidikan Kesehatan Metode Simulasi Menggosok
Gigi Teknik Modifikasi Bass Dengan Ketrampilan Dan Kebersihan Gigi Mulut Pada Anak Mi At-Taufiq Kelas V. Indonesian Journal of Community Health Nursing vol 1 (1). Surabaya.

8. Pradita dkk (2013). Perbedaan Tingkat Pengetahuan Kesehatan Gigi dan Mulut Sekolah Dasar di Kota (SDN Purwantoro 1 Malang) dan di desa (SDN Sukopuro 3 Kabupaten Malang). Fakultas Kedokteran Universitas Brawijaya.

9. Pintauli, Sondang dan Hamada, Taizo (2008). Menuju Gigi dan Mulut Sehat Pencegahan dan Pemeliharaan. USU Press. Medan.

10. Barus, Dumasari (2009). Hubungan Kebiasaan Makan Dan Pemeliharaan Kesehatan Gigi Dengan Karies Gigi Pada Anak SD 060935 Di Jalan Pintu Air Simpang Gudang Kota Medan Tahun 2008. [Skripsi]. USU.

11. Sihite, Jesica N (2011). Hubungan Perilaku Pemeliharaan Kesehatan Gigi Dan Mulut Dengan Pengalaman Karies Dan Indeks Oral Hygiene Pada Murid Smp. [Skripsi]. FKG USU. Medan.

12. Dinas Kesehatan Kota Padang (2013). Laporan Tahunan Kesehatan Gigi dan Mulut. Dinkes Kota Padang. Padang.

13. Puskesmas Andalas (2013). Laporan Hasil Skrening Kesehatan Murid SD Negeri Puskesmas Andalas Tahun 2013. Padang.

14. Angela, Ami (2005). Pencegahan Primer pada Anak yang Beresiko Karies Tinggi. Maj. Ked.Gigi (Dent. J.)Vol 38 (3) Hal 130-134. Medan.

15. Noviani, Nita (2010). Faktor Faktor yang Berhubungan dengan Status Karies Gigi (DMFT) Santri Pesantren Al Ashriyyah Nurul Iman Parung Bogor tahun 2010. [Tesis]. Universitas Indonesia.I

16. Bachtiar dkk (2005). Peran Buah dan Sayur dalam menurunkan keparahan karies gigi pada anak.[Artikel Ilmiah]. Fakultas Kesehatan Masyarakat Universitas Siliwangi Tasikmalaya.

17. Almeida dkk (2008). Saliva Composition and Functions: A Comprehensive review. The Journal of Contemporary Dental Practice Vol 9 (3) 
Hal 1-11.

18. Loveren C, Decker RT (2003). Sugar and dental caries. Am J Clin Nur.

19. Hiremath, SS (2011). Textbook of Preventive and Community Dentistry. Elsevier. India.
20. Notohartojo dkk (2011). Nilai Karies Gigi pada Karyawan Kawasan Industry di Pulo Gadung Jakarta. Media Litbang Kesehatan Vol 21 (4) hal 166-175. Jakarta.

21. Tarigan (2013). Karies Gigi Edisi 2. EGC. Jakarta. 